\title{
Herbicidal and Fungicidal Effects of Cuminum cyminum, Mentha longifolia and Allium sativum Essential Oils on Some Weeds and Fungi
}

\author{
Tamer Üstüner $^{\oplus 1^{*}}$,Saban Kordali ${ }^{\oplus 2}$ and Ayse Usanmaz Bozhüyük ${ }^{\oplus 3}$ \\ ${ }^{I}$ Plant Protection Department, Agriculture Faculty, University of Kahramanmaras Sutcu Imam, \\ Kahramanmaras, Türkiye \\ ${ }^{2}$ Plant Protection Department, Fethiye Agriculture Faculty, University of Mugla Sitkı Kocman, Mugla, \\ Türkiye \\ ${ }^{3}$ Plant Protection Department, Agriculture Faculty, University of Igdır, Igdır, Türkiye
}

(Received April 28, 2018; Revised June 8, 2018; Accepted June 10, 2018)

\begin{abstract}
In this study, chemical compositions of essential oil extracted from Cuminum cyminum L., Mentha longifolia L. and Allium sativum L. were analysed using GC and GC-MS methods. The herbicidal effects of the essential oils on seed germination, root and shoot growth of Rumex crispus L. and Convolvulus arvensis L. were investigated. Meanwhile their effects regarding the mycelial development in Verticilium dahlia Kleb. and Fusarium oxysporum Schl. were also evaluated. Only the highest three concentrations; $10,15,20 \mu \mathrm{g} / \mathrm{cm}^{2}$ of $A$. sativum L. were $100 \%$ inhibited the seed germination, root and shoot growth of $R$. crispus L.; C. cyminum L. and M. longifolia L were affected at a rate of $100 \%$ by the four concentrations. All the three essential oils showed significant effect (100\%) in the parameters examined against $C$. arvensis L. The essential oils obtained from $C$. cyminum L., M. longifolia L. and A. sativum L. were found to be $100 \%$ effective on $V$. dahlia Kleb. mycelium growth in all concentrations examined. However, C. cyminum L. and M. longifolia L. essential oils were found to be $30.0-36.6 \%$ effective at the concentration of $5 \mu \mathrm{g} / \mathrm{cm}^{2}$ on mycelium development of $F$. oxysporum Schl.; and the other 3 concentrations totally inhibited the growth of the fungi. The essential oil of A. sativum L. was the most effective; and $100 \%$ inhibition of the mycelial growth of $F$. oxysporum was detected in all concentrations. The oils used in the study have the potential of being used as herbicides and fungicides.
\end{abstract}

Keywords: Cuminum cyminum L.; Mentha longifolia L.; Allium sativum L.; essential oil; weed; fungi. (C) 2018 ACG Publications. All rights reserved.

\section{Introduction}

In recent years, researchers have focused on the ways to increase the food production because of the fast-growing demand related to the growth of the world population. Avoiding or mitigating crop losses due to plant diseases caused by pathogenic fungi, bacteria and weeds are one of the most important issues in plant production [1]. Synthetic pesticides are known to cause serious environmental pollution owing to their slow biodegradation. Consequently, scientists around the globe have focused on finding new potential biological pesticides which will show different selective pesticidal mechanisms in comparison to synthetic chemicals. Recently, there has been a growing interest for research concerning alternative pesticides and antimicrobial active compounds, including plant extracts and essential oils [2-7]. Odorous plants and their volatile compounds affect seed germination and plant growth, and therefore hold a great potential for

\footnotetext{
* Corresponding author: E-Mail: tamerustuner@ksu.edu.tr ; Phone: 03443002060; Fax: 03443002002
} 
agricultural purposes especially as plant growth regulators and bioherbicides [8]. Phytochemical analysis showed that $C$. cyminum L.,

M. longifolia L. and A. sativum L. contained alkaloid, anthraquinone, coumarin, flavonoid, glycoside, protein, resin, saponin, tannin, steroid and cardiac glycosides [9-11].

One of the most important problems is weed in agriculture. Although the use of synthetic herbicides in controlling weeds in agriculture is effective for some weeds, it can cause soil, water and environmental pollution. [12]. Because of this, biological control against weeds is important. In biological fight, there is no negative impact on the soil, water and environment. The phytotoxic effects of volatile oils of aromatic plants have increased the interest in exploring for potential weed management [13]. Studies have reported that the main allelopathic effects of essential oils on weeds slow the growth and development of weeds as well as inhibiting germination of their seeds [14,15]. Allelopathic effects of some essential oil plants such as Mentha spicata L., Origanum onites L., Rosmarinus officinalis L., Salvia officinalis L. and Thymbra spicata L. were investigated against some common weed species such as Amaranthus retroflexus L., Rumex nepalensis Spreng. and Sinapis arvensis L. that posed problems in the field and horticultural crops [16].

The Verticillium and Fusarium species have fairly wide host ranges. These species are soil-borne fungi and they can even survive for extended periods in the absence of a host plant by producing resilient resting structures. The application of fungicides to eradicate these species should be phased out because of the increasing attention to environmental and human health and the development of fungicide resistance $[17,18]$. Consequently, alternative control strategies would be useful in reducing health hazards, environmental damage and the pollution potential [19]. Biofungicides may be an attractive alternative method to be used against these species. The antifungal assays showed that Origanum acutidens oil, carvacrol and thymol completely inhibited mycelial growth of 17 phytopathogenic fungi; and their antifungal effects were higher than commercial fungicide, benomyl [6]. Besides, C. cyminum L. essential oils possessed antifungal activity against Botrytis cinerea, Rhizopus stolonifer and Aspergillus niger such that the incorporation of $750 \mu \mathrm{l} / \mathrm{L}$ from $C$. cyminum L. oils to PDA medium completely inhibited the growth of these three species [20]. Essential oil extracted from the leaves of Mentha arvensis (43.45\% menthol) was evaluated in vitro; and it was found to completely inhibit the growth of two pathogenic filamentous fungi, A. niger and A. flavus [21].

In the present study, the purpose was to evaluate the pesticidal effect of the essential oil isolated from C. cyminum L., M. longifolia L. and A. sativum L. on some fungi and weeds.

\section{Materials and Methods}

\subsection{The Plant Materials and Isolation of Essential Oils}

The seeds of $C$. cyminum L. (Apiaceae) and the bulbs of A. sativum L. (Amaryllidaceae) were taken from the market. The leaves of M. longifolia L. (Lamiaceae) at flowering stage were collected from Erzurum region of Turkey between June and August of 2016. The plant materials were identified by Ass.Prof.Dr. Y. Ziya Kocabas from the University of Kahramanmaras, Turkoglu Vocational School (Kahramanmaras, Turkey). Herbarium number of specie is M. longifolia L (YZK 2190). Erzurum is located on the Latitude $39^{\circ} 57^{\prime} 23^{\prime \prime} \mathrm{N}$ and longitude $41^{\circ} 10^{\prime} 12^{\prime \prime} \mathrm{E}$, its annual average temperature is $9.4{ }^{\circ} \mathrm{C}$ while its altitude reaches about $1900 \mathrm{~m}$.

The seeds of $C$. cyminum $\mathrm{L}$ were dried at $70^{\circ} \mathrm{C}$, grinded to powders and placed in a desiccator prior to use. Garlic (A. sativum L.) bulbs were finely chopped and dried in shade. The bulbs were finely sliced and the leaves of $M$. longifolia $\mathrm{L}$. were dried and powdered in a grinder. The dried samples $(500 \mathrm{~g})$ were subjected to hydrodistillation for 4 hours using a Clevenger-type apparatus. The hydrodistillation of aromatic plants yielded the accumulations of its essential oil at a rate of $1.5 \%(\mathrm{w} / \mathrm{w})$. The oils were dried over anhydrous $\mathrm{Na}_{2} \mathrm{SO}_{4}$ and stored under $\mathrm{N}_{2}$ in a sealed vial at $4{ }^{\circ} \mathrm{C}$ until used for herbicidal and fungicidal effect bioassays. 
Table 1. Chemical composition of essential oil of C. cyminum L. and M. longifolia L.

C. cyminum L. M .longifolia $\mathrm{L}$.

\begin{tabular}{|c|c|c|c|c|}
\hline $\mathbf{R I}^{\mathbf{a}}$ & $\mathbf{R I}^{\mathbf{b}}$ & Compounds & Composition $\%$ & Composition $\%$ \\
\hline 922 & $908-931^{\mathrm{a}, \mathrm{b}, \mathrm{c}}$ & $\alpha$-thujene & 0.30 & - \\
\hline 931 & $912-939^{a, b, c}$ & $\alpha$ pinene & 29.20 & \\
\hline 954 & $954-971^{\mathrm{a}, \mathrm{c}, \mathrm{e}, \mathrm{f}}$ & sabinene & 0.60 & 0.30 \\
\hline 973 & $967-979^{\mathrm{b}, \mathrm{c}, \mathrm{d}, \mathrm{f}}$ & $\beta$-pinene & 9.05 & 0.70 \\
\hline 988 & $981-990^{\mathrm{a}, \mathrm{b}, \mathrm{c}, \mathrm{f}}$ & myrcene & 0.60 & $\mathrm{t}$ \\
\hline 990 & $990-996^{\mathrm{d}, \mathrm{e}, \mathrm{f}}$ & 3-octanol & - & 0.10 \\
\hline 1018 & $1013-1017^{\mathrm{b}, \mathrm{c}, \mathrm{d}, \mathrm{f}}$ & $\alpha$-terpinene & $\mathrm{t}$ & $\mathrm{t}$ \\
\hline 1025 & $1013-1025^{a, b, c, d}$ & $p$-cymene & 0.30 & $\mathrm{t}$ \\
\hline 1029 & $\begin{array}{l}1025- \\
1029^{\mathrm{a}, \mathrm{b}, \mathrm{c}, \mathrm{d}, \mathrm{e}, \mathrm{f}}\end{array}$ & limonene & 21.70 & 0.90 \\
\hline 1051 & $1051-1059^{a, b, c, e}$ & $\gamma$ - terpinene & 0.60 & 0.63 \\
\hline 1030 & $1030-1032^{b, c, e, f}$ & 1,8-cineole & 18.10 & 0.10 \\
\hline 1082 & $1082-1090^{\mathrm{a}, \mathrm{f}}$ & terpinolene & 0.30 & $\mathrm{t}$ \\
\hline 1093 & $\begin{array}{c}1089- \\
1110, \text { a,b,d,e,f }\end{array}$ & linalool & $\mathrm{t}$ & 0.20 \\
\hline 1153 & $1153-1155^{\mathrm{d}, \mathrm{e}}$ & menthone & - & 7.03 \\
\hline 1169 & $\begin{array}{c}1169- \\
1183^{\mathrm{a}, \mathrm{c}, \mathrm{d}, \mathrm{e}, \mathrm{f}}\end{array}$ & terpinene-4-ol & 0.50 & 0.60 \\
\hline 1182 & $1182-1188^{\mathrm{c}, \mathrm{f}}$ & $p$-cymen-8-ol & 0.40 & 0.40 \\
\hline 1180 & $1180-1189^{\mathrm{a}, \mathrm{c}, \mathrm{d}}$ & $\alpha$-terpineole & 3.17 & 0.40 \\
\hline 1248 & $1248^{\mathrm{a}}$ & linalyl acetate & 4.80 & - \\
\hline 1262 & $1256-1262^{\mathrm{d}, \mathrm{f}}$ & $\begin{array}{l}\text { trans-piperitone } \\
\text { epoxide }\end{array}$ & - & 48.70 \\
\hline 1290 & $1290^{c}$ & p-ceymen-7-ol & 4.60 & - \\
\hline 1294 & $1290-1294^{\mathrm{c}, \mathrm{d}, \mathrm{f}}$ & thymol & 2.80 & 1.40 \\
\hline 1343 & $1342-1343^{\mathrm{f}}$ & piperitenone & - & 0.40 \\
\hline 1373 & $1368-1373^{\mathrm{d}, \mathrm{e}, \mathrm{f}}$ & $\begin{array}{l}\text { piperitenone } \\
\text { oxide }\end{array}$ & - & 21.20 \\
\hline 1425 & $1419-1425^{\mathrm{f}}$ & $\begin{array}{c}(E)- \\
\text { caryophyllene }\end{array}$ & - & 2.30 \\
\hline 1436 & $1432-1436^{\mathrm{d}, \mathrm{f}}$ & $\beta$-copaene & - & 0.60 \\
\hline 1456 & $1456-1489^{b, f}$ & germacrene D & 0.10 & 9.80 \\
\hline 1500 & $1500-1504^{\mathrm{d}, \mathrm{f}}$ & $\begin{array}{c}\text { bicyclogermacr } \\
\text { ene }\end{array}$ & - & 0.40 \\
\hline 1506 & $1480-1506^{\mathrm{d}, \mathrm{e}, \mathrm{f}}$ & $\alpha$-muurolene & - & 0.30 \\
\hline 1529 & $1513-1529^{\mathrm{d}, \mathrm{e}, \mathrm{f}}$ & $\gamma$-cadinene & - & 0.20 \\
\hline \multicolumn{3}{|c|}{ Monoterpene hydrocarbons } & 40.35 & 2.50 \\
\hline & \multicolumn{2}{|c|}{ Sesquiterpene hydrocarbons } & 37.70 & 77.56 \\
\hline & \multicolumn{2}{|c|}{ Oxygenated sesquiterpenes } & - & 14.10 \\
\hline & \multicolumn{2}{|l|}{ Benzenoids } & 9.57 & 1.80 \\
\hline & \multicolumn{2}{|c|}{ Aliphatic compounds } & 9.50 & 0.70 \\
\hline & & $\begin{array}{l}\text { Total } \\
\text { identified (\%) }\end{array}$ & 97.12 & 96.66 \\
\hline
\end{tabular}

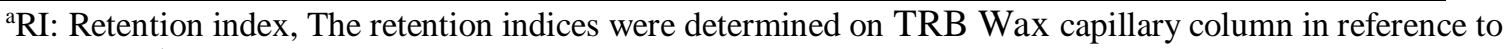
$n$-alkanes; bRI : Retention index of literature; a) [23], b) [24], c) [25], d) [26], e) [27] and f) [28]; t: trace $(<0.05 \%)$.

\subsection{Gas Chromatography-Mass Spectrometry (GC-MS) Analysis}

Gas chromatography-Mass spectrometry (GC/MS) was used for the identification of the components in aromatic plants essential oil. GC/MS instrument (GC/MS-QP 2010 Plus Shimadzu, Japan) fitted with a TRB Wax capillary column ( $30 \mathrm{~m} \times 0.25 \mathrm{~mm}$ i.d., $0.25 \mu \mathrm{m}$ film thickness) was used for qualitative determination. Essential oils were diluted $1 / 10$ in $\mathrm{n}$-hexane (v/v) prior to the analysis. For GC-MS detection, an electron impact ionization system with ionization energy of $70 \mathrm{eV}$ was used. Carrier gas was 
Helium at a flow rate of $1.0 \mu \mathrm{L} / \mathrm{min}$. Injector and MS transfer line temperatures were set at $220^{\circ} \mathrm{C}$ and $290^{\circ} \mathrm{C}$, respectively (Tables 1 and 2). The oven temperature was programmed to raise from $50^{\circ} \mathrm{C}$ to $150^{\circ} \mathrm{C}$ at $3{ }^{\circ} \mathrm{C} / \mathrm{min}$, then to hold isothermal for $10 \mathrm{~min}$, and was finally raised to $250^{\circ} \mathrm{C}$ at $10^{\circ} \mathrm{C} / \mathrm{min}$. The components were identified based on the comparison of their relative retention time (RI) and mass spectra with the standards of Wiley7N, TRLIB library data of the GC-MS system and literature data [22].

Table 2. Chemical composition of essential oil of A. sativum L. accordig to GC-MS

\begin{tabular}{|c|c|c|c|}
\hline $\mathbf{R I}^{\mathbf{a}}$ & $\mathbf{R I}^{\mathbf{b}}$ & Compounds & Composition \% \\
\hline 739 & $739-767^{\mathrm{g}, \mathrm{h}}$ & dimethyl disulfide & 0.40 \\
\hline 741 & $741-776^{\mathrm{g}, \mathrm{h}}$ & 2-methyl-4-pentenal & $\mathrm{t}$ \\
\hline 743 & $743^{\mathrm{g}}$ & 2-methylene-4-pentenal & 0.40 \\
\hline 801 & $801-802^{\mathrm{g}, \mathrm{h}}$ & hexanal & $\mathrm{t}$ \\
\hline 842 & $842^{\mathrm{g}}$ & 1,2-dithiolane & 0.50 \\
\hline 854 & $848-855^{\mathrm{g}, \mathrm{h}}$ & diallyl sulfide & 6.59 \\
\hline 870 & $867-870^{\mathrm{g}, \mathrm{h}}$ & allyl propyl sulfide & $\mathrm{t}$ \\
\hline 916 & $915-916^{\mathrm{g}, \mathrm{h}}$ & allyl methyl disulfide & 4.40 \\
\hline 928 & $928^{g}$ & $\begin{array}{l}\text { methyl }(Z) \text {-1-propenyl } \\
\text { disulfide }\end{array}$ & 0.40 \\
\hline 936 & $936^{\mathrm{g}}$ & $\begin{array}{l}\text { methyl }(E) \text {-1-propenyl } \\
\text { disulfide }\end{array}$ & 0.60 \\
\hline 953 & $953^{\mathrm{g}}$ & 1,2-dithiolene & 0.30 \\
\hline 968 & $955-968^{\mathrm{g}, 1}$ & dimethyl trisulfide & 2.00 \\
\hline 1080 & $1079-1084^{\mathrm{g}, \mathrm{h}, \mathrm{l}}$ & diallyl disulfide & 20.80 \\
\hline 1100 & $1100^{\mathrm{g}}$ & $\begin{array}{l}\text { allyl (E)-1-propenyl } \\
\text { disulfide }\end{array}$ & 5.20 \\
\hline 1131 & $1131-1138^{\mathrm{g}, \mathrm{h}}$ & allyl methyl trisulfide & 19.20 \\
\hline 1181 & $1181-1183^{1}$ & 2-vinyl-1.3-dithiane & 3.90 \\
\hline 1301 & $1301-1305^{\mathrm{g}}$ & diallyl trisulfide & 33.40 \\
\hline 1313 & $1313^{\mathrm{g}}$ & allyl propyl trisulfide & 0.20 \\
\hline 1325 & $1325^{\mathrm{g}}$ & $\begin{array}{l}\text { allyl (E) -1-propenyl } \\
\text { trisulfide }\end{array}$ & - \\
\hline 1540 & $1538-1555^{\mathrm{g}}$ & diallyl tetrasulfide & 1.50 \\
\hline \multicolumn{3}{|c|}{ Monoterpene hydrocarbons } & 12.79 \\
\hline \multicolumn{3}{|c|}{ Sesqiterpene hydrocarbons } & 74.60 \\
\hline \multicolumn{3}{|c|}{ Oxygenated monoterpenes } & 6.70 \\
\hline \multicolumn{3}{|c|}{ Oxygenated sesquiterpenes } & 4.70 \\
\hline \multicolumn{3}{|c|}{ Others } & 1.00 \\
\hline \multicolumn{3}{|c|}{ Total identified (\%) } & 99.79 \\
\hline
\end{tabular}

${ }^{a} \mathrm{RI}$ : Retention index, The retention indices were determined on TRB Wax capillary column in reference to $n$-alkanes; ${ }^{\mathrm{RI}}$ : Retention index of literature; g) [29], h) [30] and 1) [31]; t: trace $(<0.05 \%)$.

\subsection{Fungal Material}

The plant pathogenic fungi were obtained from the culture collection at Atatürk University. These fungi were identified by Prof.Dr. Saban Kordali from the University of Atatürk, Department of Plant Protection (Erzurum, Turkey). All fungus cultures were maintained on potato dextrose agar (PDA) and stored at $4^{\circ} \mathrm{C}$. The fungal species used in the experiments were $V$. dahliae Kleb. (SK 510) and $F$. oxyporum Schl. (SK 511). Antifungal activity was studied by using a contact assay (in vitro), which produces hyphal growth inhibition. Briefly, potato dextrose agar (PDA) plates were prepared in $9 \mathrm{~cm}$ diameter glass petri dishes. The essential oil was dissolved in dimethyl sulfoxide (DMSO) (Merck) at different concentrations $(1 \%, \mathrm{v} / \mathrm{v})\left(0.25,0.5\right.$ and $1.0 \mathrm{mg} / \mathrm{mL}$ concentration) and required amounts of the solutions $\left(20.0 \mu \mathrm{g} / \mathrm{cm}^{2}\right)$ were added to each of the PDA plates containing $20 \mathrm{~mL}$ of agar at $50^{\circ} \mathrm{C}$. A disc $(5 \mathrm{~mm}$ diameter) of the fungal species was cut from 1 week old cultures on PDA plates and then the mycelial surface of the disc was placed upside down on the centre of a dish with fungal species in contact with growth medium on the dish. Then, the plates were incubated in the dark at $25 \pm 2^{\circ} \mathrm{C}$. The diameters of the fungal species used in the dishes were measured at 24-hour intervals for 7 days. Mean of growth measurements was calculated from 
four replicates of each of the fungal species. PDA plates containing DMSO \pm water solution $(1 \%, \mathrm{v} / \mathrm{v})$, without essential oil solution were used as negatory control. In addition, PDA plates treated with captan wp $\left(20.0 \mu \mathrm{g} / \mathrm{cm}^{2}\right)$ were used as positive control. Mycelial growth inhibition (GI) was calculated as a percentage from the difference between growth of treated and control mycelium using the following equation:

$$
\text { GI }(\%)=\frac{\mathrm{C}-\mathrm{T}}{\mathrm{C}} \times 100
$$

Here, $\mathrm{C}$ is the mean of the hyphal extension $(\mathrm{mm})$ of negative controls, and $\mathrm{T}$ is the mean of the hyphal extension $(\mathrm{mm})$ of the plates treated with the tested compounds.

\subsection{Weed Material and Seedling Growth Experiments}

The seeds of $R$. crispus L. and $C$. arvensis L. were gathered in the Erzurum region (Turkey) in October 2016. The weed materials were identified by Ass.Prof.Dr. Y. Ziya Kocabas from the University of Kahramanmaras, Turkoglu Vocational School (Kahramanmaras, Turkey). Herbarium numbers of species are $R$. crispus L. (YZK 2188) and C. arvensis L. (YZK 2189) Empty and undeveloped seeds were discarded by floating in tap water. To avoid possible inhibition caused by toxins from fungi or bacteria, the seeds were surface sterilized with $15 \%$ sodium hypochlorite for $20 \mathrm{~min}$. and then rinsed with abundant distilled water. Trifluralin (Mega-Tref 48 EC) was used as a positive control. To determine the contact herbicidal effect of the oil, the oil was dissolved in DMSO-water solution $(10 \%, \mathrm{v} / \mathrm{v})$. The emulsions were transferred to Petri dishes ( $9 \mathrm{~cm}$ diameter) with two layers of filter paper placed on the bottom. Afterwards, 50 seeds of $R$. crispus L. and C. arvensis L. were placed on the filter paper [33]. Petri dishes were closed with an adhesive tape to prevent escaping of the volatile compounds and were kept at $23 \pm 2^{\circ} \mathrm{C}$ on a growth chamber supply with $12 \mathrm{~h}$ of fluorescent light and humidity of 80\% [34]. After 10 days, the number of germinated seeds was determined and stem and root lengths were measured. Germination was measured as the percentage of seeds from which a radicle emerges. The treatments were arranged in a completely randomized design with three replications including controls.

\subsection{Statistical Analysis}

In order to determine whether there were statistically significant differences among the obtained results for antifungal and herbicidal activity assays, variance analyses were carried out using SPSS 20 software package. Differences between means were tested by Duncan test and values with $p \leq 0.05$ were considered significantly different.

\section{Results and Discussion}

The major constituents detected in the seed oil from $C$. cyminum L. were $\alpha$-pinene $(29.20 \%)$, limonene (21.70), 1,8-cineole (18.10), $\beta$-pinene (9.05) and linalyl acetate (4.8). Also, in the leaf oil of $M$. longifolia L., we identified trans-piperidone epoxide (48.70\%), piperidone oxide (21.20), germacrene D (9.80), and menthone (7.03), respectively. Additionally, we also identified the essential oils of A. sativum L. identified diallyl trisulfide (33.40\%), diallyl disulfide (20.80), allyl methyl trisulfide (19.20), allyl (E)-1propenyl disulfide (5.20) and 2-vinyl-1.3-dithiane (3.90). These volatile oil compounds and ratios were found to be similar to previous studies in this regard [22-32].

\subsection{The Herbicidal Effects of Essential Oil}

The influences of different concentrates of volatile oils obtained from these odorous plants $(C$. cyminum L., M. longifolia L. and A. sativum L.) were determined separately on $R$. crispus $\mathrm{L}$. and $C$. arvensis $\mathrm{L}$. seed germination, root and shoot growth. The Trifluralin active herbicide used as a positive control was determined for seed germination of weeds tested (Table 3). Essential oils and herbicide were used on seed germination, root and shoot growth of weeds $\left(5,10,15\right.$ and $\left.20 \mu \mathrm{g} / \mathrm{cm}^{2}\right)$. 
Table 3. Herbicidal effects of $C$. cyminum L., M. longifolia L. and A. sativum L. essential oils on R. crispus L. seed germination, root and shoot growth.

\begin{tabular}{|c|c|c|c|c|c|c|c|}
\hline Essential oils & $\mathbf{C}$ & Germination(\%) & $\begin{array}{c}\text { Germination } \\
\text { inhibition rate }(\%)\end{array}$ & $\begin{array}{l}\text { Root growth } \\
(\mathbf{m m})\end{array}$ & $\begin{array}{c}\text { Root growth } \\
\text { inhibition rate } \\
(\%)\end{array}$ & $\begin{array}{c}\text { Shoot } \\
\text { growth(mm) }\end{array}$ & $\begin{array}{c}\text { Shoot growth } \\
\text { inhibition rate } \\
(\%)\end{array}$ \\
\hline \multirow[t]{5}{*}{ Cuminum cyminum $\mathrm{L}}$. & 5 & $0.00 \pm 0.00 \mathrm{a}$ & 100 & $0.00 \pm 0.00 \mathrm{a}$ & 100 & $0.00 \pm 0.00 \mathrm{a}$ & 100 \\
\hline & 10 & $0.00 \pm 0.00 \mathrm{a}$ & 100 & $0.00 \pm 0.00 \mathrm{a}$ & 100 & $0.00 \pm 0.00 \mathrm{a}$ & 100 \\
\hline & 15 & $0.00 \pm 0.00 \mathrm{a}$ & 100 & $0.00 \pm 0.00 \mathrm{a}$ & 100 & $0.00 \pm 0.00 \mathrm{a}$ & 100 \\
\hline & 20 & $0.00 \pm 0.00 \mathrm{a}$ & 100 & $0.00 \pm 0.00 \mathrm{a}$ & 100 & $0.00 \pm 0.00 \mathrm{a}$ & 100 \\
\hline & 5 & $0.00 \pm 0.00 \mathrm{a}$ & 100 & $0.00 \pm 0.00 \mathrm{a}$ & 100 & $0.00 \pm 0.00 \mathrm{a}$ & 100 \\
\hline \multirow[t]{4}{*}{ Mentha longifolia $\mathrm{L}$. } & 10 & $0.00 \pm 0.00 \mathrm{a}$ & 100 & $0.00 \pm 0.00 \mathrm{a}$ & 100 & $0.00 \pm 0.00 \mathrm{a}$ & 100 \\
\hline & 15 & $0.00 \pm 0.00 \mathrm{a}$ & 100 & $0.00 \pm 0.00 \mathrm{a}$ & 100 & $0.00 \pm 0.00 \mathrm{a}$ & 100 \\
\hline & 20 & $0.00 \pm 0.00 \mathrm{a}$ & 100 & $0.00 \pm 0.00 \mathrm{a}$ & 100 & $0.00 \pm 0.00 \mathrm{a}$ & 100 \\
\hline & 5 & $21.6 \pm 1.08 \mathrm{~b}$ & 77.5 & $0.65 \pm 1.11 \mathrm{a}$ & 96.6 & $1.60 \pm 2.46 \mathrm{~b}$ & 92.5 \\
\hline \multirow[t]{4}{*}{ Allium sativum $\mathrm{L}$. } & 10 & $0.00 \pm 0.00 \mathrm{a}$ & 100 & $0.00 \pm 0.00 \mathrm{a}$ & 100 & $0.00 \pm 0.00 \mathrm{a}$ & 100 \\
\hline & 15 & $0.00 \pm 0.00 \mathrm{a}$ & 100 & $0.00 \pm 0.00 \mathrm{a}$ & 100 & $0.00 \pm 0.00 \mathrm{a}$ & 100 \\
\hline & 20 & $0.00 \pm 0.00 \mathrm{a}$ & 100 & $0.00 \pm 0.00 \mathrm{a}$ & 100 & $0.00 \pm 0.00 \mathrm{a}$ & 100 \\
\hline & 5 & $100 \pm 0.0 \mathrm{~d}$ & -3.84 & $1.66 \pm 0.48 \mathrm{c}$ & 91.45 & $3.42 \pm 0.92 \mathrm{c}$ & 84.08 \\
\hline \multirow[t]{3}{*}{$\begin{array}{l}\text { P. control } \\
\text { (Trifluralin) }\end{array}$} & 10 & $100 \pm 0.0 \mathrm{~d}$ & -3.84 & $\begin{array}{c}1.54 \pm 0.63 \\
b c\end{array}$ & 92.07 & $3.10 \pm 0.74 \mathrm{c}$ & 85.57 \\
\hline & 15 & $100 \pm 0.0 \mathrm{~d}$ & -3.84 & $\begin{array}{c}1.49 \pm 0.50 \\
b c\end{array}$ & 92.32 & $2.60 \pm 0.88 \mathrm{c}$ & 87.90 \\
\hline & 20 & $100 \pm 0.0 \mathrm{~d}$ & -3.84 & $1.14 \pm 0.23 b$ & 94.12 & $2.92 \pm 1.07 \mathrm{c}$ & 86.41 \\
\hline $\begin{array}{c}\text { N. control } \\
\text { (Sterile water+Ethanol) }\end{array}$ & - & $96.3 \pm 2.10 \mathrm{c}$ & - & $\begin{array}{c}19.42 \pm 7.81 \\
\mathrm{~d}\end{array}$ & - & $21.49 \pm 5.70 \mathrm{~d}$ & - \\
\hline
\end{tabular}

*The differences between the averages with different letters in each column are statistically significant $(\mathrm{P} \leq 0.05)$. C: Concentration, P: Positive, N: Negative

It has been determined that $C$. cyminum L. and M. longifolia L. inhibits $100 \%$ of root and shoot growth of $R$. crispus L. seeds at 4 different concentrations $5,10,15$ and $20 \mu \mathrm{g} / \mathrm{cm}^{2}$. The Trifluralin active herbicide was determined to be ineffective for seed germination of weeds tested (Figure S1). It was found that A. sativum L. volatile oil inhibited seed germination, root and shoot growth of $R$. crispus L. $100 \%$ at the concentrations of 10, 15 and $20 \mu \mathrm{g} / \mathrm{cm}^{2}$ (Figures S2, S3). The volatile oil of $C$. cyminum L. completely inhibited $C$. arvensis L. seed germination, root and shoot growth at 5, 10, 15 and $20 \mu \mathrm{g} / \mathrm{cm}^{2}$ (Table 4).

Table 4. Herbicidal effects of $C$. cyminum L., M. longifolia L. and A. sativum L. essential oils on C. arvensis L. seed germination, root and shoot growth.

\begin{tabular}{|c|c|c|c|c|c|c|c|}
\hline Essential oils & $\mathbf{C}$ & $\begin{array}{c}\text { Germination } \\
(\%)\end{array}$ & $\begin{array}{c}\text { Germination } \\
\text { Inhibition } \\
\text { rate }(\%)\end{array}$ & $\begin{array}{c}\text { Root Growth } \\
(\mathbf{m m})\end{array}$ & $\begin{array}{l}\text { Root Growth } \\
\text { Inhibition } \\
\text { rate }(\%)\end{array}$ & $\begin{array}{l}\text { Shoot Growth } \\
(\mathrm{mm})\end{array}$ & $\begin{array}{c}\text { Shoot Growth } \\
\text { Inhibition } \\
\text { rate }(\%) \\
\end{array}$ \\
\hline \multirow[t]{5}{*}{ Cuminum cyminum $\mathrm{L}}$. & 5 & $0.00 \pm 0.00 \mathrm{a}$ & 100 & $0.00 \pm 0.00 \mathrm{a}$ & 100 & $0.00 \pm 0.00 \mathrm{a}$ & 100 \\
\hline & 10 & $0.00 \pm 0.00 \mathrm{a}$ & 100 & $0.00 \pm 0.00 \mathrm{a}$ & 100 & $0.00 \pm 0.00 \mathrm{a}$ & 100 \\
\hline & 15 & $0.00 \pm 0.00 \mathrm{a}$ & 100 & $0.00 \pm 0.00 \mathrm{a}$ & 100 & $0.00 \pm 0.00 \mathrm{a}$ & 100 \\
\hline & 20 & $0.00 \pm 0.00 \mathrm{a}$ & 100 & $0.00 \pm 0.00 \mathrm{a}$ & 100 & $0.00 \pm 0.00 \mathrm{a}$ & 100 \\
\hline & 5 & $0.00 \pm 0.00 \mathrm{a}$ & 100 & $0.00 \pm 0.00 \mathrm{a}$ & 100 & $0.00 \pm 0.00 \mathrm{a}$ & 100 \\
\hline \multirow[t]{4}{*}{ Mentha longifolia L. } & 10 & $0.00 \pm 0.00 \mathrm{a}$ & 100 & $0.00 \pm 0.00 \mathrm{a}$ & 100 & $0.00 \pm 0.00 \mathrm{a}$ & 100 \\
\hline & 15 & $0.00 \pm 0.00 \mathrm{a}$ & 100 & $0.00 \pm 0.00 \mathrm{a}$ & 100 & $0.00 \pm 0.00 \mathrm{a}$ & 100 \\
\hline & 20 & $0.00 \pm 0.00 \mathrm{a}$ & 100 & $0.00 \pm 0.00 \mathrm{a}$ & 100 & $0.00 \pm 0.00 \mathrm{a}$ & 100 \\
\hline & 5 & $0.00 \pm 0.00 \mathrm{a}$ & 100 & $0.00 \pm 0.00 \mathrm{a}$ & 100 & $0.00 \pm 0.00 \mathrm{a}$ & 100 \\
\hline \multirow[t]{4}{*}{ Allium sativum $\mathrm{L}$. } & 10 & $0.00 \pm 0.00 \mathrm{a}$ & 100 & $0.00 \pm 0.00 \mathrm{a}$ & 100 & $0.00 \pm 0.00 \mathrm{a}$ & 100 \\
\hline & 15 & $0.00 \pm 0.00 \mathrm{a}$ & 100 & $0.00 \pm 0.00 \mathrm{a}$ & 100 & $0.00 \pm 0.00 \mathrm{a}$ & 100 \\
\hline & 20 & $0.00 \pm 0.00 \mathrm{a}$ & 100 & $0.00 \pm 0.00 \mathrm{a}$ & 100 & $0.00 \pm 0.00 \mathrm{a}$ & 100 \\
\hline & 5 & $93.0 \pm 0.0 \mathrm{c}$ & 3.62 & $1.75 \pm 0.54 \mathrm{c}$ & 64.7 & $3.50 \pm 0.84 \mathrm{~d}$ & 80.5 \\
\hline \multirow{3}{*}{$\begin{array}{l}\text { P. control } \\
\text { (Trifluralin) }\end{array}$} & 10 & $90.0 \pm 0.0 \mathrm{~b}$ & 6.73 & $1.37 \pm 0.43 b$ & 72.3 & $2.73 \pm 0.76 \mathrm{c}$ & 84.8 \\
\hline & 15 & $87.1 \pm 0.0 \mathrm{~b}$ & 9.74 & $1.23 \pm 0.40 \mathrm{~b}$ & 75.2 & $2.00 \pm 0.60 \mathrm{~b}$ & 88.8 \\
\hline & 20 & $88.8 \pm 0.0 \mathrm{~b}$ & 7.97 & $1.18 \pm 0.38 b$ & 76.2 & $1.66 \pm 0.63 b$ & 90.7 \\
\hline N. control & - & $96.5 \pm 1.44 \mathrm{~d}$ & - & $4.96 \pm 2.60 \mathrm{~d}$ & - & $18.00 \pm 6.79 \mathrm{e}$ & - \\
\hline
\end{tabular}

*The differences between the averages with different letters in each column are statistically significant $(\mathrm{P} \leq 0.05)$. C: Concentration, P: Positive, N: Negative 
It has been determined that $M$. longifolia $\mathrm{L}$. fully eradicated $C$. arvensis $\mathrm{L}$. seed germination, root and shoot growth at the concentrations of 5, 10, 15 and $20 \mu \mathrm{g} / \mathrm{cm}^{2}$ (Figure S4). It has been seen that $A$. sativum $\mathrm{L}$. volatile oil inhibited $C$. arvensis $\mathrm{L}$. seed germination, root and shoot growth $100 \%$ at the concentrations of $5,10,15$ and $20 \mu \mathrm{g} / \mathrm{cm}^{2}$ (Figures S5, S6).

\subsection{The Fungicidal Effects of Essential Oil}

The effects of essential oils obtained from the aromatic plants $(C$. cyminum L., M. longifolia $\mathrm{L}$. and A. sativum L.) on the growth of $V$. dahlia Kleb. and $F$. oxysporum Schl. mycelium were determined separately. Meanwhile, the effect of Captan active ingredient fungicide was used as a positive control. Essential oils from $C$. cyminum L., M. longifolia L. and A. sativum L. inhibited $V$. dahlia Kleb. mycelial growth $100 \%$ at 4 different concentrations $\left(5,10,15\right.$ and $\left.20 \mu \mathrm{g} / \mathrm{cm}^{2}\right)$. Essential oils obtained from $C$. cyminum L. and M. longifolia L. inhibited 30.0-36.6\% F. oxysporum Schl. mycelial growth at $5 \mu \mathrm{g} / \mathrm{cm}^{2}$ concentration and $100 \%$ at the other 3 concentrations. Captan activa fungicide used as a positive control inhibited $100 \%$ germination of fungi tested at $10 \mu \mathrm{g} / \mathrm{cm}^{2}$ (Table 5, Figure S7).

Table 5. Fungicidal effect of evaporating oils obtained from C. cyminum L., M. longifolia L. and A. sativum L. on V. dahlia Kleb. mycelial growth.

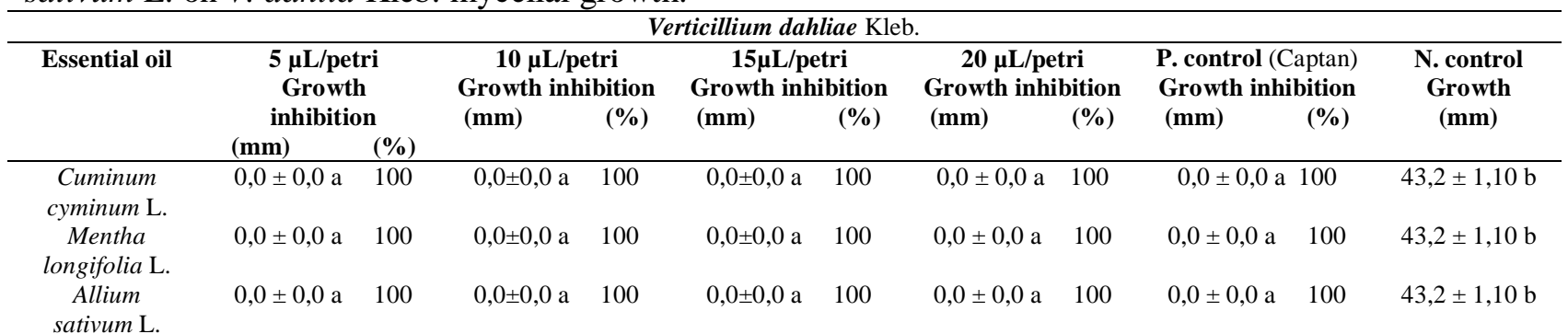

*The differences between the averages with different letters in each column are statistically significant $(\mathrm{P} \leq 0.05)$. C: Concentration, P: Positive, N: Negative

The effect of the evaporating oils acquired from $C$. cyminum L., M. longifolia $\mathrm{L}$. was found to inhibit $30.0-36.6 \%$ F. oxysporum Schl. mycelium growth at $5 \mu \mathrm{g} / \mathrm{cm}^{2}$ concentration, while $100 \%$ was inhibited in the other 3 concentrations. The effect of volatile oils obtained from A. sativum L. was $100 \%$ F. oxysporum Schl. mycelium development at the concentrations of 5, 10, 15 and $20 \mu \mathrm{g} / \mathrm{cm}^{2}$ (Table 6, Figure S8).

Table 6. Antifungal effect of $F$. oxysporum Schl. mycelial growth of volatile oils obtained from $C$. cyminum L., M. longifolia L. and A. sativum L.

\begin{tabular}{|c|c|c|c|c|c|c|c|c|}
\hline \multicolumn{9}{|c|}{ Fusarium oxysporum Schl. } \\
\hline \multirow[t]{2}{*}{ Essential oil } & $\begin{array}{c}5 \mu \mathrm{L} / \text { petri } \\
\text { Growth inhibition }\end{array}$ & $\begin{array}{c}10 \mu \mathrm{L} / \text { petri } \\
\text { Growth inhibition }\end{array}$ & \multicolumn{2}{|c|}{$\begin{array}{c}15 \mu \mathrm{L} / \text { petri } \\
\text { Growth inhibition }\end{array}$} & $\begin{array}{c}20 \mu \mathrm{L} / \text { petri } \\
\text { Growth inhibition }\end{array}$ & \multicolumn{2}{|c|}{$\begin{array}{l}\text { P. control (Captan) } \\
\text { growth inhibition }\end{array}$} & \multirow{2}{*}{$\begin{array}{l}\text { N. control } \\
\text { Growth } \\
(\mathrm{mm})\end{array}$} \\
\hline & $(\mathrm{mm}) \quad(\%)$ & $(\mathrm{mm})$ & $(\mathrm{mm})$ & $(\%)$ & $(\mathrm{mm})$ & $(\mathrm{mm})$ & $(\%)$ & \\
\hline $\begin{array}{l}\text { Cuminum cyminum } \\
\text { L. }\end{array}$ & $30.0 \pm 1.98$ b 26,4 & $0,0 \pm 0,0 \mathrm{a}$ & $0,0 \pm 0,0 \mathrm{a}$ & 100 & $0,0 \pm 0,0 \mathrm{a}$ & $0,0 \pm 0,0 \mathrm{a}$ & 100 & $40,8 \pm 1,00 \mathrm{~d}$ \\
\hline Mentha longifolia $\mathrm{L}$. & $36,6 \pm 2,21$ c 10,2 & $0,0 \pm 0,0$ a 100 & $0,0 \pm 0,0 \mathrm{a}$ & 100 & $0,0 \pm 0,0 \mathrm{a}$ & $0,0 \pm 0,0 \mathrm{a}$ & 100 & $40,8 \pm 1,00 \mathrm{~d}$ \\
\hline Allium sativum $\mathrm{L}$. & $0,0 \pm 0,0$ a 100 & $0,0 \pm 0,0 \mathrm{a}$ & $0,0 \pm 0,0 \mathrm{a}$ & 100 & $0,0 \pm 0,0$ a 100 & $0,0 \pm 0,0 \mathrm{a}$ & 100 & $40,8 \pm 1,00 \mathrm{~d}$ \\
\hline
\end{tabular}

*The differences between the averages with different letters in each column are statistically significant $(\mathrm{P} \leq 0.05)$. $\mathrm{C}$ : Concentration, P: Positive, N: Negative

Synthetic pesticides have caused many serious economic and environmental problems due to their broad-spectrum toxicity. Therefore $C$. cyminum L., M. longifolia L. and A. sativum L. essential oil compounds were investigated as natural alternative to be used against to weeds and pathogenic fungi at different concentrations for $7^{\text {th }}$ days, in vitro. The tested essential oils $(C$. cyminum L., M. longifolia $\mathrm{L}$. and A. sativum L.) were found to be $100 \%$ effective against $R$. crispus L. used at 10,15 and $20 \mu \mathrm{g} / \mathrm{cm}^{2}$ concentrations on $7^{\text {th }}$ day. These three volatile oils were found to inhibit seed $100 \%$ germination, root and shoot growth of $C$. arvensis L. at a rate of $100 \%$ at 4 concentrations $\left(5,10,15\right.$ and $\left.20 \mu \mathrm{g} / \mathrm{cm}^{2}\right)$. Trifluralin, 
which was used as a positive control, was found not to prevent the weed germination at all doses and its effect was statistically insignificant.

In other studies conducted in Turkey and worldwide, it was determined that the rates of the essential oil compounds vary according to the plants and extraction methods. The fungicidal effects of the essential oils obtained at various rates from different plants varied on weeds. It was reported that the essential oils like the $\alpha$-pinene, limonene, 1,8-cineole, $\beta$-pinene, linalyl acetate, trans-piperidone epoxide, piperidone oxide, germacrene $\mathrm{D}$, diallyl trisulfide, diallyl disulfide, allyl methyl trisulfide, which are obtained from Amaryllidaceae, Anacardiaceae, Apiaceae, Asteraceae, Lamiaceae and Myrtaceae families, prevented the germination of weeds. The killing effects of essential oils on germination, growth of roots and offshoots of weeds were found to be different. They were found to be influential on many weeds like A. retroflexus, $C$. album, $C$. arvensis, C. juncea, Lolium rigidum, $R$. crispus, Trifolium repens, P. angulata, S. arvensis, Setaria viridis and Phalaris minor. It was reported that these herbicidal effects varied between 1-100\% [3545].

These (C. cyminum L., M. longifolia L.and A. sativum L.) volatile oils were found to be $100 \%$ effective in 3 concentrations $\left(10,15\right.$ and $20 \mu \mathrm{g} / \mathrm{cm}^{2}$ ) on $F$. oxysporum Schl. mycelial growth, while 4 concentrations $\left(5,10,15\right.$ and $\left.20 \mu \mathrm{g} / \mathrm{cm}^{2}\right)$ were effective on $V$. dahlia Kleb. Additionally,Captan activa fungicide, which was used as a positive control, inhibited the germination of fungi tested at a rate of $100 \%$ at the concentration $10 \mu \mathrm{g} / \mathrm{cm}^{2}$.

In a previous investigation, the mycelial growth of most fungi used in the study was affected by the essential oil, which shows the potential of this oil and its inhibitory effect against some important pathogenic fungi. Similarly, it was also found that these essential oils were effective on fungal pathogens at various rates. It was also reported that the fungicidal effects varied between $1-100 \%$ on pathogens like $B$. cinerea, F. avenaceum, Fusarium culmorum, F. oxysporum ,Fusarium solani, F. subglutinans, Pythium ultimum, Rhizoctonia cerealis, $R$. solani and $V$. dahlia [23, 45-53].

\section{Conclusion}

There are many reports supporting the results of our work concerning with the development of new alternative pesticides, such as fungal pathogens and weeds, toxic natural products including plant essential oils, extracts and secondary metabolites for pest control in agriculture.

These results suggest that $C$. cyminum L., M. longifolia $\mathrm{L}$. and $A$. sativum $\mathrm{L}$. essential oil might have the potential to be used as natural herbicide as well as fungicides.

\section{Supporting Information}

Supporting Information accompanies this paper on http://www.acgpubs.org/RNP

\section{ORCID ID}

Tamer Üstüner: 0000-0003-3584-4249

Şaban Kordali: 0000-0001-5669-5831

Ayşe Usanmaz Bozhüyük: 0000-0003-2450-6850

\section{References}

[1] F. Dadasoglu, T. Aydin, R. Kotan, A. Cakir, H. Ozer, S. Kordali, R. Cakmakci, N. Dikbas and E. Mete (2011). Antibacterial activities of extracts and essential oils of three origanum species against plant pathogenic bacteria and their potential use as seed disinfectants, J. Plant Path. 93, 271-282.

[2] H. Basim, O. Yegen and W. Zelker (2000). Antibacterial effect of essential oils of Thymbra spicata L. var spicata on some plant pathogenic bacteria, J. Plant Dis. Protec. 107, 279-284.

[3] M. Sokmen, J. Serkedjleva, D. Dalerera, M. Gulluce, M. Pollissiou, B. Tepe, H.A. Akpulat, F. Sahin and A. Sökmen (2004). In vitro antioxidant, antimicrobial and antiviral activities of the essential oil and various extracts from herbal parts and callus cultures of Origanum acutidens, J. Agric. Food Chem. 52, 3309-3312.

[4] S. Kizil and F. Uyar (2006). Antimicrobial activities of some thyme (Thymus, Satureja, Origanum and Thymbra) species against important plant pathogens, Asian J. Chem. 18, 1455-1461. 
[5] S. Kordali, R. Kotan and A. Cakir (2007). Screening of in-vitro antifungal activities of 21 oxygenated monoterpenes as plant disease control agents, Allelopathy J. 19, 373-392.

[6] S. Kordali, A. Cakir, H. Ozer, R. Cakmakci, M. Kesdek and E. Mete (2008). Antifungal, phytotoxic and insecticidal properties of essential oil isolated from Turkish Origanum acutidens and its three components, carvacrol, thymol and pcymene, Elsevier, Bio. Tech. 99, 8788-8795.

[7] R. Kotan, A. Cakir, F. Dadasoglu, T. Aydin, R. Cakmakci, H. Ozer, S. Kordali, E. Mete and N. Dikbas (2010). Antibacterial activities of essential oils and extracts of Turkish Achillea, Satureja and Thymus species against plant pathogenic bacteria, J. Sci. Food and Agri. 90, 145-160.

[8] D. Chaimovitsh, A. Shachter, M. Abu-Abied, B. Rubin, E. Sadot and N. Dudai. (2017). Herbicidal activity of monoterpenes is associated with disruption of microtubule functionality and membrane integrity, Weed Sci. 65 , 19-30.

[9] N. Rai, S. Yadav, A.K. Verma, L. Tiwari and R.K. Sharma (2012). A monographic profile on quality specifications for a herbal drug and spice of commerce Cuminum cyminum L., Int. J. Advan. Herbal Sci. Tech. 1, 1-12.

[10] R.A. Khan, N.A. Khan, F.U. Khan, M. Ahmed, A.S. Shah, M.R. Khan and M.S. Shah (2012). Phytochemical, antioxidant and cytotoxic activities of Periploca aphyla and Mentha longifolia, selected medicinal plants of district Bannu, Afr. J. Pharm. Pharmacol. 6, 3130-3135.

[11] U. Huzaifa, I. Labaran, A.B. Bello and A. Olatunde (2014). Phytochemical screening of aqueous extract of Garlic (Allium sativum) bulbs, Rep. Opinion. 6, 1-4.

[12] M.J. Kropff and H. Walter (2000). EWRS and the challenges for weed research at the start of a new millennium, Weed Res. 40, 7-10.

[13] F.E. Dayan, C.L. Cantrell and S.O. Duke (2009). Natural products in crop protection, Bio. \& Medic. Chem. Lett. 17, 4022-4034.

[14] V. Feo, F. Simone and F. Senatore (2002). Potential allelochemicals from the essential oil of Ruta graveolens, Phytochem. 61, 573-578.

[15] J.N. Barney, A.G. Hay and L.A.Weston (2005). Isolation and characterization of allelopathic volatiles from mugwort (Artemisia vulgaris), J. Chem. Ecol. 31, 247-265.

[16] S. Azirak and S. Karaman (2008). Allelopathic effect of some essential oils and components on germination of weed species, J. Acta Agri. Scand., Section B Soil \& Plant Sci. 58, 88-92.

[17] K.L. Everts, D.S. Egel, D. Langston, X.-G. Zhou (2014). Chemical management of Fusarium wilt of watermelon, Crop Prot. 66, 114-119.

[18] T.A. Brimner and G.J. Boland (2003). A review of the non-target effects of fungi used to biologically control plant diseases, Agric. Ecosyst. Environ. 100, 3-16.

[19] M. Ros, M.T. Hernandez, C. Garcia, A. Bernal and J.A. Pascual (2005). Biopesticide effect of green compost against Fusarium wilt on melon plants, J. Appl. Microbiol. 98, 845-854.

[20] J. Hadian, M. Ghasemnezhad, H. Ranjbar, M. Frazane and M. Ghorbanpour (2008). Antifungal potency of some essential oils in control of postharvest decay of strawberry caused by Botrytis cinerea, Rhizopus stolonifer and Aspergillus niger, J. Ess. Oil Bear. Plants (JEOBP), 11,553-562.

[21] R.R. Pandey, R.C. Dubey and S. Saini (2010). Phytochemical and antimicrobial studies on essential oils of some aromatic plants, Afr. J. Biotech. 9, 4364-4368.

[22] R.P. Adams (2007). Identification of essential oil components by gas hromatography/mass spectrometry, Carol Stream, Illinois, $4^{\text {th }}$ Ed., Allured Pub.Corp. 1-804.

[23] H. Mohammadpour, E. Moghimipour, I. Rasooli, M.H. Fakoor, S.A. Astaneh, S.S. Moosaie and Z. Jalili (2012). Chemical composition and antifungal activity of Cuminum cyminum L. essential oil from Alborz mountain against Aspergillus species, Jundishapur J. Nat. Pharm. Prod. 7, 50-55.

[24] R. Li and Z.T. Jiang (2004). Chemical composition of the essential oil of Cuminum cyminum L. from China, Flavour Fragr. J. 19, 311-313.

[25] V.S. Rana (2014). Chemical composition of the essential oil of Cuminum cyminum L. seeds from Western India, J. Med. Plants by-prod. 2, 207-210.

[26] M. Gulluce, F. Sahin, M. Sokmen, H. Ozer, D. Daferera, A. Sokmen, M. Polissiou, A. Adiguzel and H. Ozkan (2006). Antimicrobial and antioxidant properties of the essential oils and methanol extract from Mentha longifolia L. ssp. longifolia, Food Chem.103,1449-1456.

[27] M. Mkaddem, J. Bouajila, M. Ennajar, A. Lebrihi, F. Mathieu and M. Romdhane (2009). Chemical composition and antimicrobial and antioxidant activities of Mentha (longifolia L. and viridis) essential oils, J. Food Sci. 74, M358-363.

[28] R.S. Verma, V. Pandey, A. Chauhan and R. Tiwari (2015). Essential oil composition of Mentha longifolia L. collected from Garhwal region of Western-Himalaya, J. Ess. Oil Bear. Plant (JEOBP). 18, 957-966. 
[29] P. Satyal, J.D. Craft, N.S. Dosoky and W.N. Setzer (2017). The Chemical Compositions of the Volatile Oils of Garlic (Allium sativum) and Wild Garlic (Allium vineale), Foods 6, 63.

[30] D.Mnayer, A.-Sy. Fabiano-Tixier, E. Petitcolas, T. Hamieh, N. Nehme, C. Ferrant, X. Fernandez and F. Chemat (2014). Chemical composition, antibacterial and antioxidant activities of six essentials oils from the Alliaceae family, Molecules 19, 20034-20053.

[31] S. Dziri, H. Casabianca, B. Hanchi and K. Hosni (2014). Composition of garlic essential oil (Allium sativum L.) as influenced by drying method, J. Essen.Oil Res. 26, 91-96.

[32] M. Altun and A.C. Gören (2007). Essential oil composition of Satureja cuneifolia by simultaneous distillationextraction and thermal desorption GC-MS techniques, J. Ess. Oil-Bear. Plant (JEOBP). 10, 139-144.

[33] A.J. Fradi and A.M.Y. Al-Araji (2015). Effect of Eucalyptus camaldulensis terpenes, alkaloids and phenols against Fusarium oxysporum, Iraqi J. Sci. 56, 2807-2810.

[34] S. Kordali, A. Usanmaz, A Cakir, A. Komaki and S. Ercisli (2016). Antifungal and herbicidal effects of fruit essential oils of four Myrtus communis Genotypes, Chemis. Biodiver. 13, 77-84.

[35] I. Kadioglu and Y. Yanar (2004). Allelopathic effects of plant extracts against seed germination of some weeds, Asian J. Plant Sci. 3, 472-475.

[36] B.K. Yildırım (2007). Investigation of the bioherbicidal effects of certain herbal essential oils, Master Thesis (Unpublished), Ondokuz Mayıs University, Institute of Science, Samsun, Turkey.

[37] S. Kordali, A. Cakir and S. Sutay (2007). Inhibitory effects of monoterpenes on seed germination and seedling growth, Z. Naturforsch. C. 62, 207-214.

[38] S. Kordali, A. Cakir, T. A. Akcin, E. Mete, T. Aydin and H. Kilic (2009). Antifungal and herbicidal properties of essential oils and n-hexane extracts of Achillea gypsicola Hub-Mor. and Achillea biebersteinii Afan. (Asteraceae), Ind. Crop. Prod. 29, 562-570.

[39] O. Aydın and N. Tursun (2010). Determination of allelopathic effects of some plant originated essential oils on germination and emergence of some weed seeds, KSU J. Nat. Sci. 13, 11-17.

[40] I. Amri, L. Hamrouni, M. Hanana and B. Jamoussi (2013). Reviews on phytotoxic effects of essential oils and their individual components: news approach for weeds management, Int.. J. Applied Biol. Pharma. Tech. 2, 69114.

[41] A.R. Rahimi, S.J. Mousavizadeh, H. Mohammadi, A. Rokhzadi, M. Majidi and S. Amini (2013). Allelopathic effect of some essential oils on seed germination of Lathyrus annuus and Vicia villosa, J. Biodiver. Envir. Sci. 3, 67-73.

[42] I.B.H. Jilani, S. Chebil, R. Khiari, I. Melki, S.L.-B. Saad, A. Daoud-Bouattour and Z. Gammar-Ghrabi (2014). Allelopathic potential of some essential oils vis-à-vis three noxious weed species invading cereals, Int.. J. Agron. Agri. Res. 4, 77-97.

[43] W.M.A. El Azim and M.A. Balah (2016). Nanoemulsions formation from essential oil of Thymus capitatus and Majorana hortensis and their use in weed control, Ind. J. Weed Sci. 48, 421-427.

[44] A. Cakır, H. Özer, T. Aydın, S. Kordali, A. T. Cavusoglu, T. Akcin, E. Mete and A. Akcin (2016). Phytotoxic and insecticidal properties of essential oils and extracts of four Achillea species, Rec. Nat. Prod. 10, 154-167.

[45] M. Hanana, M.B. Mansour, M. Algabr, I. Amri, S. Gargouri, A. Romane, B. Jamoussi and L. Hamrouni (2017). Potential use of essential oils from four Tunisian species of Lamiaceae: Biological alternative for fungal and weed control, Rec. Nat. Prod. 11, 258-269.

[46] A. Zambonelli, A.D. Aulerio, A. Bianchi and A. Albasini (1996). Effects of essential oils on phytopathogenic fungi in vitro, J. Phytopath. 94, 491-495.

[47] M.D. Soković and L.J.L.D. Van Griensven (2006). Anti microbial activity of essential oils and their components against the three major pathogens of the cultivated button mushroom, Agaricus bisporus, The Eur. J. Plant Path. 116, 211-224.

[48] L. Hu, C. Chen, X. Yi, J. Feng and X. Zhang (2008). Inhibition of p-isopropyl benzaldehyde and p-isopropyl benzoic acid extracted from Cuminum cyminum against plant pathogens, Acta Bot. Boreali Occidentalia Sin. 28, 2349-2354.

[49] M. Arslan and S. Dervis (2010). Antifungal activity of essential oils against three vegetative-compatibility groups of Verticillium dahliae, World J. Micro. Biotechnol. 26, 1813-1821.

[50] E.A. Elsherbinya, B.H. Aminb and Z.A. Bakac (2016). Efficiency of pomegranate (Punica granatum L.) peels extract as a high potential natural tool towards Fusarium dry rot on potato tubers, Post. Biol. Tech. 111, 256263.

[51] A. Onaran and H.D. Saglam (2017). Evaluation of the biocontrol potential of Morina persica L. extract against Ditylenchus dipsaci (Kühn) Filipjev and some plant pathogenic fungi, COMU J. Agric. Fac. 5, 63-68. 
[52] Y. Sun,Y. Wang, L.R. Han, X. Zhang and J.T. Feng (2017). Antifungal activity and action mode of Cuminic acid from the Seeds of Cuminum cyminum L. against Fusarium oxysporum f. sp. niveum (FON) causing Fusarium wilt on watermelon, Molecules 22, 1-13.

[53] A.Varo, A. Mulero-Aparicio, M. Adem, L.F. Roca, M.C. Raya-Ortega, F.J. Lopez-Escudero and A. Trapero (2017). Screening water extracts and essential oils from Mediterranean plants against Verticillium dahliae in olive, Crop. Protec. 92, 168-175.

$$
\begin{gathered}
\text { A } \\
\text { publications } \\
\text { (C) 2018 ACG Publications }
\end{gathered}
$$

